\title{
Characterization and function of the human macrophage dopaminergic system: implications for CNS disease and drug abuse
}

\author{
Peter J Gaskill' ${ }^{1}$ Loreto Carvallo ${ }^{1}$, Eliseo A Eugenin ${ }^{1,2}$ and Joan W Berman ${ }^{1,3^{*}}$
}

\begin{abstract}
Background: Perivascular macrophages and microglia are critical to CNS function. Drugs of abuse increase extracellular dopamine in the CNS, exposing these cells to elevated levels of dopamine. In rodent macrophages and human T-cells, dopamine was shown to modulate cellular functions through activation of dopamine receptors and other dopaminergic proteins. The expression of these proteins and the effects of dopamine on human macrophage functions had not been studied.
\end{abstract}

Methods: To study dopaminergic gene expression, qRT-PCR was performed on mRNA from primary human monocyte derived macrophages (MDM). Expression and localization of dopaminergic proteins was examined by immunoblotting isolated plasma membrane, total membrane and cytosolic proteins from MDM. To characterize dopamine-mediated changes in cytokine production in basal and inflammatory conditions, macrophages were treated with different concentrations of dopamine in the presence or absence of LPS and cytokine production was assayed by ELISA. Statistical significance was determined using two-tailed Students' T-tests or Wilcoxen Signed Rank tests.

Results: These data show that MDM express mRNA for all five subtypes of dopamine receptors, and that dopamine receptors 3 and 4 are expressed on the plasma membrane. MDM also express mRNA for the dopamine transporter (DAT), vesicular monoamine transporter 2 (VMAT2), tyrosine hydroxylase (TH) and aromatic amino acid decarboxylase (AADC). DAT is expressed on the plasma membrane, VMAT2 on cellular membranes and TH and AADC are in the cytosol. Dopamine also alters macrophage cytokine production in both untreated and LPS-treated cells. Untreated macrophages show dopamine mediated increases IL-6 and CCL2. Macrophages treated with LPS show increased IL-6, CCL2, CXCL8 and IL-10 and decreased TNF-a.

Conclusions: Monocyte derived macrophages express dopamine receptors and other dopaminergic proteins through which dopamine may modulate macrophage functions. Thus, increased CNS dopamine levels due to drug abuse may exacerbate the development of neurological diseases including Alzheimer's disease and HIV associated neurological disorders.

Keywords: Monocyte derived macrophage, Dopamine, Drug abuse, Cytokine, Neuroinflammation dopamine receptor, Dopamine transporter, Tyrosine hydroxylase, Aromatic amino acid decarboxylase

\footnotetext{
* Correspondence: joan.berman@einstein.yu.edu

'Department of Pathology, Albert Einstein College of Medicine, Bronx, NY, USA

${ }^{3}$ Department of Microbiology and Immunology, Albert Einstein College of Medicine, Bronx, NY, USA

Full list of author information is available at the end of the article
} 


\section{Background}

In individuals who abuse drugs such as cocaine and methamphetamine [1,2], extracellular dopamine in different regions of the brain is increased, exposing perivascular macrophages and microglia to elevated concentrations of dopamine [3-5]. Central nervous system (CNS) dopamine is also increased by therapeutic drugs including antidepressants [6], L-DOPA [7,8], methylphenidate [9], cholinergic agents for treatment of Alzheimer's disease [10], as well as by stress [11], depression [12,13] and neuropathologies such as HIV-associated neurological disorders (HAND) [14] and schizophrenia [15,16]. Little is known about the effects of dopamine on human macrophages, although studies in rodent macrophages and microglia, as well as in human T-cells indicate that exposure to high concentrations of dopamine significantly impacts the function of macrophages and microglia [1724]. Perivascular macrophages and microglia are central to CNS function [25], and dysfunction in these cell types is associated with the development of many neurological disorders [26,27]. Therefore, we characterized the macrophage dopaminergic system and examined the effects of dopamine on macrophages to define mechanisms by which increases in CNS dopamine may contribute to the development of neuropathology.

Dopamine is synthesized by conversion of tyrosine to L-DOPA by the enzyme tyrosine hydroxylase $(\mathrm{TH})$, and L-DOPA is then converted to dopamine by aromatic amino acid decarboxylase (AADC) [28,29]. Dopamine acts through activation of dopamine receptors (DR), which are divided into two sub-classes, D1-like dopamine receptors, D1R and D5R, and D2-like dopamine receptors, D2R, D3R and D4R [30]. Dopamine receptor activation depends on CNS dopamine concentrations, which are regulated by dopamine transporter (DAT)-mediated re-uptake, metabolic breakdown by monoamine oxidases and catechol-O-methyl transferase, and diffusion into extracellular fluid [31-34]. Recaptured or newly synthesized dopamine is transported from the cytoplasm into secretory granules by vesicular monoamine transporters (VMAT), where it is stored until released [35]. Thus, the dopaminergic proteins DAT, VMAT, TH and AADC act together with DR to regulate the effects of dopamine.

Dopamine receptors are expressed on human T-cells, neutrophils, monocytes and B-cells [36]. T-cells also express $\mathrm{TH}$ and DAT, and take up, store, and synthesize dopamine as part of their regulatory processes [17,37-39]. Dopamine mediates proliferation, quiescence, chemotaxis and cytokine production in different subtypes of human T-cells [20,21,40-43] and also modulates neutrophil migration and apoptosis [44,45]. Expression of DAT, VMAT2 and AADC were detected in human myeloid cells as well as the promyelocytic U937 cell line $[46,47]$. Tyrosine hydroxylase and
VMAT2 have been found in CD163+ human macrophages from arthritic synovial tissue but not in CD163+ cells from non-arthritic controls [48]. We previously demonstrated that primary human monocyte-derived macrophages (MDM) express D2-like DR on the cell surface and activation of these receptors increases HIV replication [49]. The effects of dopamine on human macrophages are not well characterized.

To examine the response of human macrophages to the increased dopamine levels induced by drug abuse, we characterized gene and protein expression of DR, DAT, VMAT2, TH and AADC in MDM. We also studied dopaminergic effects on cytokine production in both basal and inflammatory conditions by using untreated and LPS-treated macrophages. Macrophages have been shown to express mRNA for all subtypes of DR and have $\mathrm{D} 3 \mathrm{R}$ and $\mathrm{D} 4 \mathrm{R}$ on the plasma membrane. Macrophages also expressed mRNA and protein for DAT, VMAT2, $\mathrm{TH}$ and AADC, with DAT on the plasma membrane and VMAT2 in cellular membranes. Our data demonstrated that dopamine treatment significantly increased IL-6 and CCL2 in both untreated and lipopolysaccharide (LPS)-treated MDM, increased CXCL8 and IL-10 and decreased TNF- $\alpha$ in LPS-treated MDM. These data indicate that dopamine is an important mediator of both macrophage homeostasis and of the response of macrophages to injury and infection, and that drug-induced changes in CNS dopamine may alter the development of neurological disease.

\section{Methods}

Reagents

RPMI-1640 medium and penicillin/streptomycin (P/S) were from Invitrogen (Carlsbad, CA, USA). LPS from E. Coli 055:B5, hydroxyethyl piperazineethanesulfonic acid (HEPES), fish gelatin, $\beta$-mercaptoethanol, IgG-free bovine serum albumin (BSA), horse serum, Tween 20 and dopamine hydrochloride (DA) were obtained from Sigma-Aldritch (St. Louis, MO, USA). Dopamine was resuspended at $20 \mathrm{mM}$ in $\mathrm{dH} 2 \mathrm{O}$, aliquoted and stored at $-80^{\circ} \mathrm{C}$ for up to 2 months before use. Fetal calf serum (FCS) and human AB serum were from Lonza (Basel, Switzerland). Macrophage colony stimulating factor (MCSF) was from Peprotech (Rocky Hill, NJ, USA). Antibodies used were rabbit polyclonal anti-DR3 (1:250), rabbit polyclonal anti-DR4 (1:250), rabbit polyclonal anti-VMAT2 (1:250) and rabbit polyclonal anti-AADC (1:200) (Millipore, Billerica, MA, USA), rabbit polyclonal anti-TH (1:500) (Cell Signaling Technology, Danvers, MA, USA), rabbit polyclonal anti-DAT (1:250 Western blot, 1:50 Immunofluoresence, Sigma), anti $\alpha$-tubulin $(1: 10,000)$, fluorescein isothiocyanate (FITC)-conjugated anti-rabbit secondary antibodies (Sigma), anti-rabbit IgG and anti-rabbit $\mathrm{Na}^{+} / \mathrm{K}^{+}$ATPase (1:200, Santa Cruz 
Biotechnologies, Santa Cruz, CA, USA). Other reagents were anti-fade with 4',6-diamidino-2-phenylindole (DAPI), TRIzol reagent and phalloidin conjugated to Texas red, obtained from Molecular Probes (Invitrogen).

\section{Generation of primary human macrophages}

Human peripheral blood mononuclear cells (PBMC) were separated from blood obtained from de-identified healthy donors (New York Blood Center, Long Island City, New York, USA) by Ficoll-Paque (GE Healthcare, Piscataway, NJ, USA) gradient centrifugation. After isolation of PBMC, MDM were obtained either by adherence over 3 days or by using CD14 magnetic beads (EasySep Human CD14 Positive Selection kit), according to the manufacturer's protocol (Stem Cell Technologies, Vancouver, Canada). MDM were cultured in RPMI-1640 with 10\% FCS, 5\% human AB serum, $10 \mathrm{mM} \mathrm{HEPES,} \mathrm{1 \%} \mathrm{P/S,} \mathrm{and}$ M-CSF $(10 \mathrm{ng} / \mathrm{mL})$ for 3 days, washed twice with fresh media, and cultured for another 3 days in fresh media containing M-CSF. After 6 days in culture cells were washed again and considered to be mature MDM.

\section{Quantitative RT-PCR}

Total RNA was extracted from MDM using TRIzol (Invitrogen). Purity and concentration were determined using a Nanodrop spectrophotometer (Nanodrop technologies, Wilmington, DE, USA). On the same day of the extraction, $2 \mu \mathrm{g}$ of RNA were used to synthesize cDNA from each donor using the iScript cDNA synthesis kit (Bio-Rad Laboratories Inc., Hercules, CA, USA), generating random cDNA fragments using both oligo$\mathrm{dT}$ and random primers. FirstChoice Human Brain Total RNA was used as a positive control (Ambion, Austin, TX, USA) and samples containing no cDNA served as the negative controls. Target mRNA was quantified with the Absolute Blue QPCR SYBR low ROX Mix (Thermo Scientific). Single-product amplification was confirmed by melting-curve analysis. Reactions in which the negative control showed amplification curves that were detected before 37 cycles were not used. Specific dopaminergic and housekeeping genes were amplified from cDNA by quantitative PCR (qPCR) from $1 \mu \mathrm{L}$ of cDNA reaction using gene-specific primers designed using Primer3 [50] and synthesized by Fisher Custom Oligonucleotides service (Table 1). The specificity of each primer for the gene of interest and all common splice variants was confirmed using a nucleotide BLAST search [51].

\section{Immunofluoresence and confocal microscopy}

MDM cultured on 35-mm Mat Tek dishes (Mat Tek, Ashland, MA, USA) were fixed and permeabilized in $70 \%$ ethanol for 30 minutes at $4^{\circ} \mathrm{C}$. Cells were washed in PBS, incubated in block solution (0.5 M EDTA, 1\% human $A B$ serum, $2 \%$ fish gelatin, $1 \%$ Ig-free $B S A, 1 \%$ horse serum in $\mathrm{H} 2 \mathrm{O}$ ) for 30 minutes at room temperature (RT) and then in primary antibodies (antiDAT or isotype-matched controls, all 1:50) overnight at $4^{\circ} \mathrm{C}$. Cells were washed with PBS and incubated for $1 \mathrm{hr}$ at RT with the appropriate secondary antibody conjugated to FITC (1:250, Sigma) as well as phalloidin-conjugated Texas Red (1:50, Invitrogen). Cover slips were mounted on Mat Tek dishes using Prolong Gold Antifade reagent with DAPI (Invitrogen). MDM were examined by confocal microscopy using a Leica microscope (Wetzlar, Germany).

\section{Subcellular fractionation}

Isolation of MDM plasma membrane, total membrane and cytosolic fractions was performed using a polyethylene glycol and dextran T-500-based centrifugal gradient kit, according to the manufacturer's protocol (BioVision Membrane Protein Extraction kit, Biovision, Mountain View, CA, USA). For each lysate, 20 to $40 \times 10^{6} \mathrm{MDM}$ cultured at $10 \times 10^{6} \mathrm{MDM}$ per dish were used to generate either a single plasma membrane or total membrane and cytoplasmic lysate.

Table 1 Primers used for qRT-PCR

\begin{tabular}{|c|c|c|}
\hline Primer & Forward primer sequence $\left(5^{\prime}-3^{\prime}\right)$ & Reverse primer sequence $\left(5^{\prime}-3^{\prime}\right)$ \\
\hline$\beta$-actin & СTCTTCCAGCCTTCCTTCCT & AGCACTGTGTTGGCGTACAG \\
\hline DRD1 & AGGGGAATTTGCAGTTCTGT & AAAAGATGGAGAGGGCCAAT \\
\hline DRD2 & GCAGACCACCACCAACTACC & СCACTCACCTACCACCTCCA \\
\hline DRD3 & CACTGTCTGCTCCATCTCCA & GAGGATCCTITTCCGTCTCC \\
\hline DRD4 & CCTTCTTCGTGGTGCACAT & AACTCGGCGTTGAAGACAGT \\
\hline DRD5 & GCCTACCAGAGATGGACCAA & AAAAGGGAGGGGAGAGCATA \\
\hline $\mathrm{TH}$ & GTGAGGTTGTGCTGCCTGT & CIITATTGTGACGGTGATTGG \\
\hline AADC & CGAGCAGAGAGGGAGTAGGA & CCACAGACAGCTGAGTTCCA \\
\hline VMAT2 & TTGAGGGTTTCTGGTTCTCC & ATACCTITGCCAGGCCTTCT \\
\hline DAT & CGAGCCTGCTTGCTGATATT & ATGGCATCCACTTTCCTGTC \\
\hline
\end{tabular}




\section{Immunoblotting}

Human MDM were lysed with mammalian protein extraction reagent (M-PER, Pierce, Rockford, IL, USA) with added protease (Halt Protease inhibitor cocktail, Pierce) and phosphatase inhibitors (Halt Phosphatase Inhibitor Cocktail, Pierce). For detection of $\mathrm{TH}$ and AADC, lysates were sonicated, centrifuged at $14,000 \times \mathrm{g}$, and stored at $-80^{\circ} \mathrm{C}$ until used. Loading buffer containing $\beta$-mercaptoethanol was added to lysates that were then heated to $100^{\circ} \mathrm{C}$ for 5 minutes. Western blot analyses were performed using 4 to $12 \%$ Nupage polyacrylamide gels (Invitrogen). Proteins were transferred to polyvinylidene fluoride (PVDF) membranes (Invitrogen) and blots were blocked in Tris-buffered saline (TBS-T) ( $1 \times$ TBS with $1.2 \%$ Tween 20$)$ containing $3 \%$ BSA/5\% nonfat powdered milk. Signal was detected using Supersignal WestPico Chemiluminescent substrate for TH or Supersignal WestFemto Chemiluminescent substrate for AADC (Pierce). After probing for $\mathrm{TH}$ or AADC, blots were stripped using Restore PLUS Western Stripping Buffer (Pierce) and probed for $\alpha$-tubulin as a loading control.

Plasma membrane and cytosolic lysates from the same donor were probed for either D3R, D4R or DAT, while total membrane and cytosolic fractions from the same donor were probed for VMAT2. Denaturing lysates by heating altered the mobility of the DR, DAT and VMAT2. Therefore, in place of heating, lysates were incubated in loading buffer containing $\beta$-mercaptoethanol for $45 \mathrm{~min}$ utes at RT. Western blots were run as described above, and after probing for DR or DAT, blots were stripped and reprobed for $\mathrm{Na}^{+} / \mathrm{K}^{+}$ATPase and $\alpha$-tubulin to confirm the specificity of the membrane isolations.

\section{Quantification of cytokine or chemokine secretion}

MDM cultured at $5 \times 10^{5}$ per well in 48 -well plates (BDFalcon) were incubated for 24 hrs with different concentrations of dopamine ( $20 \mathrm{nM}, 200 \mathrm{nM}, 2 \mu \mathrm{M}$ or $20 \mu \mathrm{M}$ ) in the presence or absence of LPS $(1 \mathrm{ng} / \mathrm{mL})$. LPS treatment was used to model inflammation. Controls were treated with $1 \mathrm{ng} / \mathrm{mL}$ LPS without dopamine, or were untreated. After 24 hours, supernatants were collected, aliquoted and stored at $-80^{\circ} \mathrm{C}$. Supernatants were analyzed for IL-6, CCL2, TNF- $\alpha$, CXCL8 and IL-10 using sandwich capture ELISAs was performed according to the manufacturer's protocol (Duoset ELISA Development systems, R\&D systems, Minneapolis, MN, USA). The limits of detection for ELISAs were IL-6, 23.44 pg/ $\mathrm{mL}, \mathrm{CCL} 2,31.25 \mathrm{pg} / \mathrm{mL}$, TNF- $\alpha, 15.625 \mathrm{pg} / \mathrm{mL}$, CXCL$8,31.25 \mathrm{pg} / \mathrm{mL}$ and IL-10, $62.5 \mathrm{pg} / \mathrm{mL}$.

\section{Statistical analyses}

Statistical analyses were performed using Prism 5.0 (Graphpad, La Jolla, CA, USA), using either a Wilcoxen Signed Rank Test (for experiments with $\mathrm{N} \geq 10$ ) or a two-tailed Student's T-test (for all other experiments). $\mathrm{P}<0.05$ was considered significant. To evaluate dopamine mediated changes in each cytokine, the foldchanges in the amount of each factor upon dopamine treatment from all donors were pooled and compared to the combined mean fold-change in the control condition (either untreated MDM or MDM treated with $1 \mathrm{ng} / \mathrm{mL}$ LPS), which was set to one.

\section{Results}

\section{Primary human macrophages express dopamine} receptors

We previously showed that dopamine treatment of human macrophages significantly increases HIV replication [49], and others demonstrated that dopamine alters cytokine secretion and other functions in rodent macrophages and microglia as well as in human T-cells. Dopamine mediates its effects principally through activation of dopamine receptors. Therefore we examined the expression and localization of DR in human macrophages. Our previous data demonstrated D1R and D2R on the surface of MDM [49]. To expand upon our original studies, we examined human macrophage mRNA for D3R, D4R and D5R as well as for D1R and D2R. We also examined the expression and localization of D3R and D4R on MDM. Protein expression and localization of D5R was not examined because of the lack of available antibodies that distinguish specifically between D1R and D5R. The mRNA from MDM isolated from 4 different donors was analyzed by qRT-PCR for D1R, D2R, D3R, D4R and $\mathrm{D} 5 \mathrm{R}$, as well as for the housekeeping gene $\beta$-actin as a control for proper PCR amplification. Representative plots showing the mRNA amplification from a single donor for each DR or for $\beta$-actin (red curves) are shown in Figure 1. Total Human brain RNA was used as a positive control in each amplification reaction (blue curves) and samples containing no cDNA served as the negative control (green curves) in each reaction. Among the four donors examined, the $\Delta C_{T}$ relative to $\beta$-actin for D1R was $12+/-2.4$ (mean $+/-$ $\mathrm{SD})$, for $\mathrm{D} 2 \mathrm{R}$ was $16.6+/-4.2$, for $\mathrm{D} 3 \mathrm{R}$ was $12.6+/-$ 3.7, for D4R was $14.7+/-3.7$ and for D5R was $9.6+/-3.5$. The negative control did not show amplification curves before 37 cycles in any amplification reaction.

To demonstrate that D3R and D4R are expressed on the plasma membrane of MDM, plasma membrane (PM) proteins were examined by western blotting. Representative Western blots show both D3R (Figure 2A, black arrow, $40 \mathrm{kDA}$ ) and D4R (Figure 2B, black arrow, $48 \mathrm{kDA}$ ) in the PM fraction. The western blots were stripped and probed for the plasma membrane protein $\mathrm{Na}^{+} / \mathrm{K}^{+}$ATPase, which was 


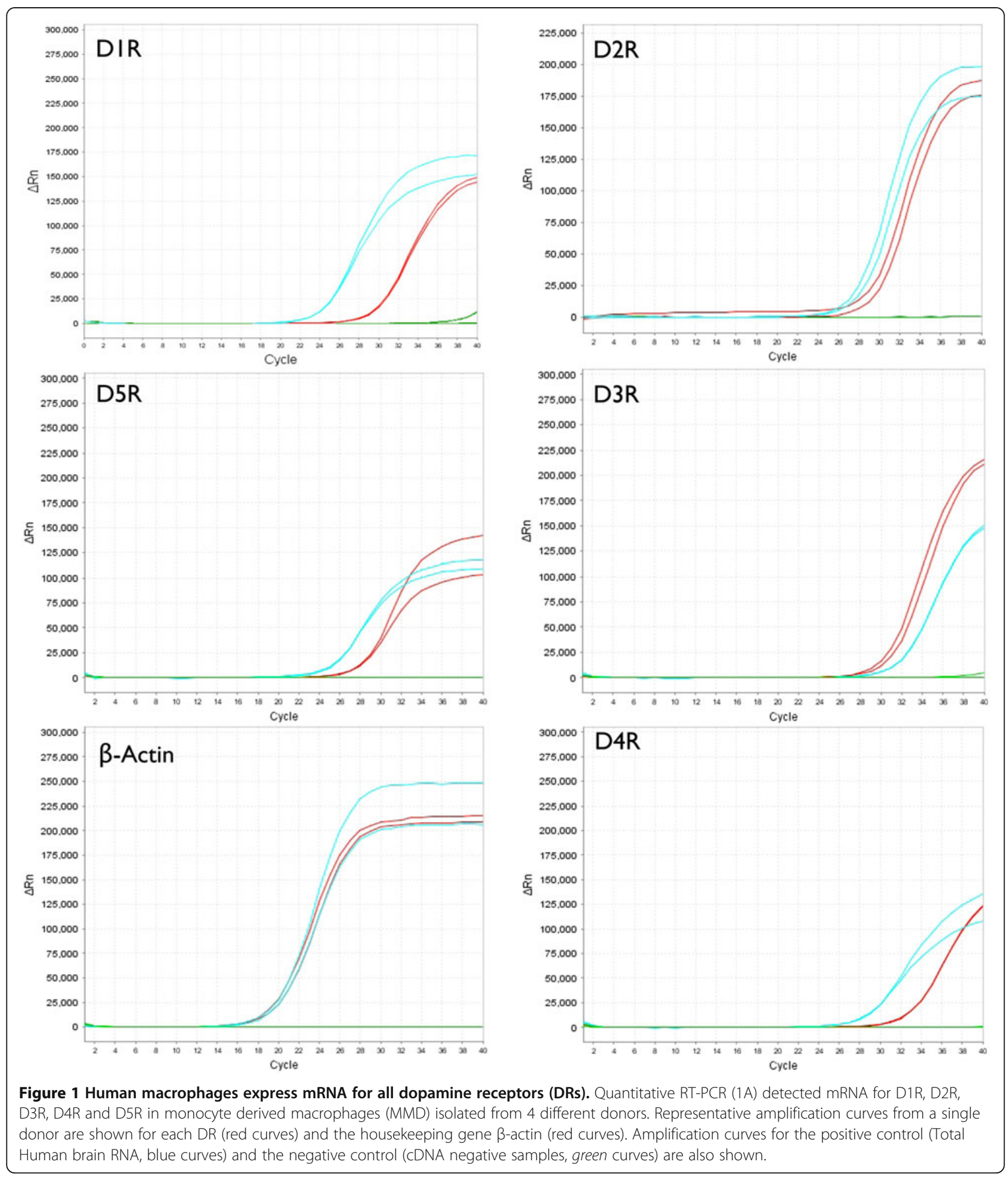

enriched in the PM fraction, and the cytosolic protein $\alpha$-tubulin, which was not found in the PM fraction, confirming the localization of the DR in the PM. These data demonstrate that human MDM express mRNA for all types of DR, and that D3R and D4R are present in the plasma membrane.

\section{Primary human macrophages express tyrosine} hydroxylase and aromatic amino acid decarboxylase

To determine whether primary human macrophages express $\mathrm{TH}$ and $\mathrm{AADC}$, and therefore have the capacity to synthesize dopamine, mRNA and protein for both were examined in human MDM from 4 different donors. 

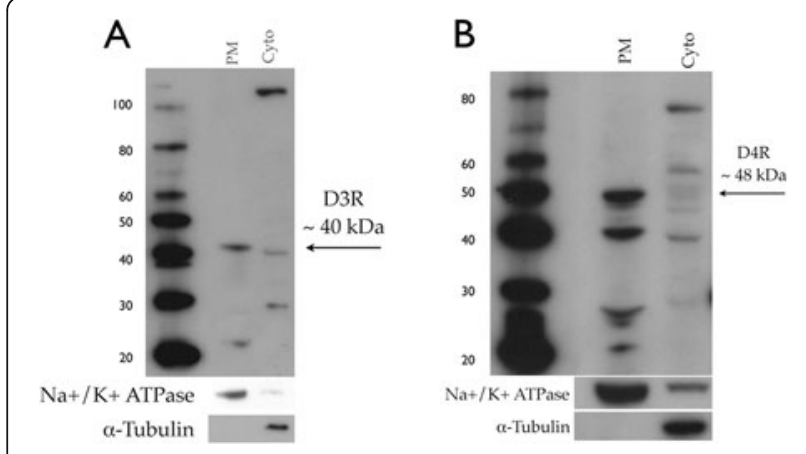

Figure 2 Human macrophages express dopamine receptors (DRs) 3 and $\mathbf{4}$ on the plasma membrane. Western blot analysis of isolated plasma membrane (PM) and cytoplasmic (Cyto) proteins from monocyte-derived macrophages (MDM) demonstrated that D3R (2B, black arrow, $40 \mathrm{kDA})$ and D4R (2C, black arrow, $48 \mathrm{kDA})$ were expressed in the PM. Specificity of the membrane protein isolation was confirmed by enrichment of $\mathrm{Na}^{+} / \mathrm{K}^{+}$ATPase and lack of a-tubulin in plasma membrane fractions (B, C).

Quantitative RT-PCR was used to amplify mRNA for $\mathrm{TH}$ and $\mathrm{AADC}$, and representative amplification curves for TH, AADC and $\beta$-actin (red curves) from a single donor are shown in Figure 3A. Total human brain RNA and cDNA negative samples used as the positive (blue curves) and negative controls (green curves) are also shown in each plot. In mRNA derived from four donors, the $\Delta \mathrm{C}_{\mathrm{T}}$ relative to $\beta$-actin was $14+/-4.6$ for $\mathrm{TH}$ and $21.1+/-3.8$ for AADC. The negative control did not show amplification curves detected before 37 cycles in any amplification reaction. Western blot analyses demonstrated both TH and AADC in MDM whole cell lysate derived from four different donors (Figure 3B, donors 1, 2, 3, $4 \mathrm{TH}$ approximately $62 \mathrm{kDA}$, AADC approximately $50 \mathrm{kDA})$. Blots were probed for $\alpha$-tubulin as a loading control. These data demonstrate that primary human macrophages express the proteins required to synthesize dopamine.

\section{Primary human macrophages express dopamine} transporter and vesicular monoamine transporter 2

To determine whether MDM have the capacity to take up dopamine from the extracellular space to the cytoplasm and transport it into storage vesicles, we analyzed expression of DAT and VMAT2 mRNA and protein from MDM derived from three different donors. Dopamine transporter was also examined by immunofluoresence. Using qRT-PCR, DAT and VMAT2 mRNA were detected in all donors examined, and representative amplification curves of these genes (red curves) and the housekeeping gene $\beta$-actin (red curve) are shown in Figure 4A. Total Human brain RNA (blue curves) and cDNA-negative (green curves) samples were used as the positive and negative controls, respectively. The $\Delta C_{T}$

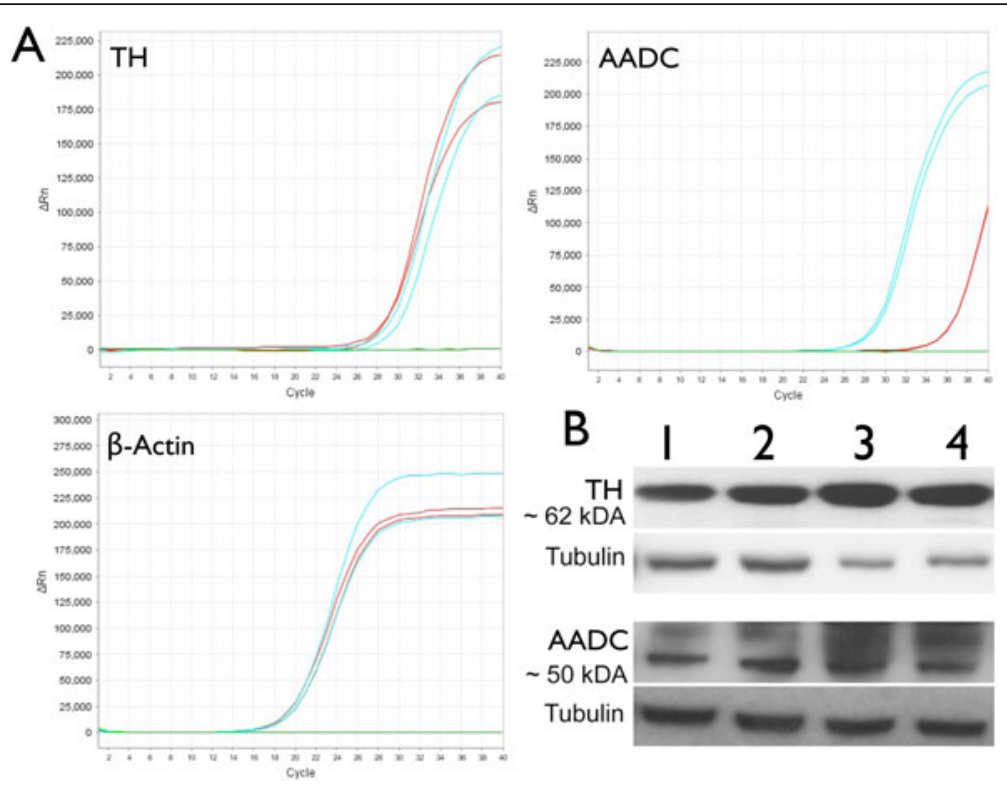

Figure 3 Human macrophages express tyrosine hydroxylase and aromatic amino acid decarboxylase. Quantitative RT-PCR (A) detected mRNA for tyrosine hydroxylase (TH) and aromatic amino acid decarboxylase (AADC) in monocyte derived macrophages (MDM) isolated from four different donors. Representative amplification curves from a single donor (A) are shown for TH, AADC (red curves) and the housekeeping gene $\beta$ actin (red curves). Amplification curves for the positive control (Total Human brain RNA, blue curves) and the negative control (cDNA negative samples, green curves) are also shown (A). Western blot analysis of MDM lysate from donors 1, 2, 3 and 4) (B) showed expression of TH (approximately $62 \mathrm{kDA}$ ) and AADC (approximately $50 \mathrm{kDA}$ ) in all donors examined. 


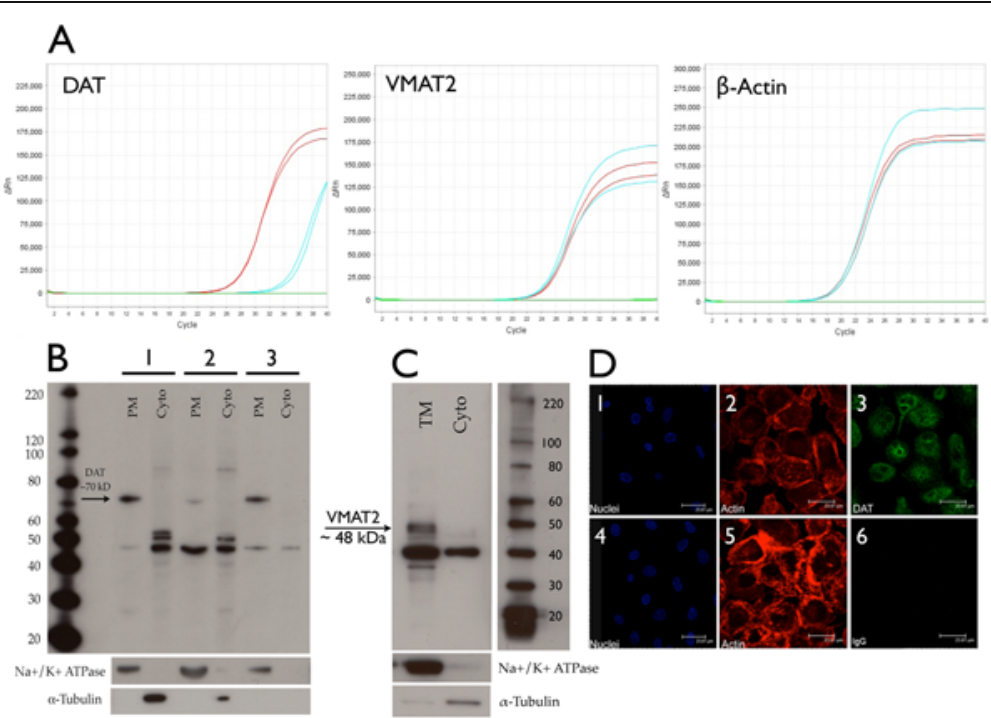

Figure 4 Macrophages express the dopamine transporter and vesicular monoamine transporter 2. Quantitative RT-PCR (A) detected mRNA for the dopamine transporter (DAT) and vesicular monoamine transporter 2 (VMAT2) in monocyte-derived macrophages (MDM) isolated from four different donors. Representative amplification curves from a single donor (A) are shown for DAT, VMAT2 (red curves) and the housekeeping gene $\beta$-actin (red curves). Amplification curves for the positive control (Total Human brain RNA, blue curves) and the negative control (cDNA negative samples, green curves) are also shown (A). Western blot analysis of isolated MDM plasma membrane (PM) and cytoplasmic (Cyto) proteins from three different donors demonstrated that DAT (B, black arrow, approximately 70 kDA) was expressed in the plasma membrane of MDM. Western blot analysis of isolated MDM total membrane (TM) and cytoplasmic (Cyto) proteins demonstrates expression of VMAT2 (4C, black arrow, approximately $48 \mathrm{kDA}$ ) in MDM membranes. Specificity of plasma and total membrane isolation was confirmed by enrichment of $\mathrm{Na}^{+} / \mathrm{K}^{+}$ATPase and lack of a-tubulin reactivity in membrane fractions (B, C). Expression of DAT is also shown in MDM stained for DAT (4D-3, FITC) or the isotype matched negative control antibody (3D-6, FITC). Cell nuclei were stained with DAPI (4D-1, -4, blue), actin was stained with Phalloidin-Texas Red (4D-2,-5, red), and the DAT or the isotype control were stained with FITC (4D-3, 6, green). Scale bars represent $23.81 \mu \mathrm{M}$.

relative to $\beta$-actin was $11.2+/-5.7$ for DAT and $8.5+/-$ 3 for VMAT2. The negative control did not show amplification detected before 37 cycles in any reaction.

Western blot analysis of plasma membrane proteins isolated from three different donors shows DAT (Figure 4B, donors 1, 2, 3, black arrow, approximately 70 kDA) and VMAT2 (Figure 4C, black arrow, approximately $48 \mathrm{kDA}$ ) in the membrane fraction (PM, plasma membrane or $\mathrm{TM}$, total membrane). We probed for VMAT2 in the total membrane fraction rather than the PM fraction because VMAT2 is found in cytoplasmic vesicles (ref for VMAT2). Neither protein was found in the cytosolic fraction (Cyto). Purity of the membrane isolation was confirmed by enrichment of $\mathrm{Na}^{+} / \mathrm{K}^{+}$ ATPase and the absence of $\alpha$-tubulin in the membrane fractions. Dopamine transporter expression on MDM was also demonstrated by immunofluorescence. Figure 4D, panels $1-3$, show DAT on the cell surface and in the cytoplasm, with cell nuclei labeled blue (4D-1 and 4D-4, DAPI), actin red (4D-2 and 4D-5, Texas Red) and DAT labeled green (4D-3, FITC). The isotypematched control antibody had minimal to no reactivity (4D-6, FITC). These data demonstrate that primary human macrophages express DAT and VMAT2 mRNA and protein, that DAT is expressed in the plasma membrane and VMAT2 is expressed in cellular membranes, and suggest that macrophages may be able to take up extracellular dopamine and store it in vesicles.

\section{Activation of dopamine receptors modulates macrophage cytokine secretion}

To examine the effect of dopamine on cytokine secretion, MDM from different donors were treated with 20 $\mathrm{nM}, 200 \mathrm{nM}, 2 \mu \mathrm{M}$ or $20 \mu \mathrm{M}$ dopamine for 24 hours in either media alone or in the presence of LPS $(1 \mathrm{ng} / \mathrm{mL})$. Control cells were treated with media alone (Untx) or LPS in the absence of dopamine. LPS was used to model the effect of dopamine on macrophage cytokine secretion in an inflammatory environment. Supernatants from each treatment condition were analyzed by ELISA for secretion of IL-6, CCL2, TNF- $\alpha$, CXCL8 or IL-10. These cytokines were selected because of their important roles in the neuroinflammation and in the development of neurological diseases such as HAND and Alzheimer's Disease. Cytokine secretion in control MDM was compared to cytokine secretion in cells treated with different concentrations of dopamine. It is important to note that the variability inherent in studying primary human cells 


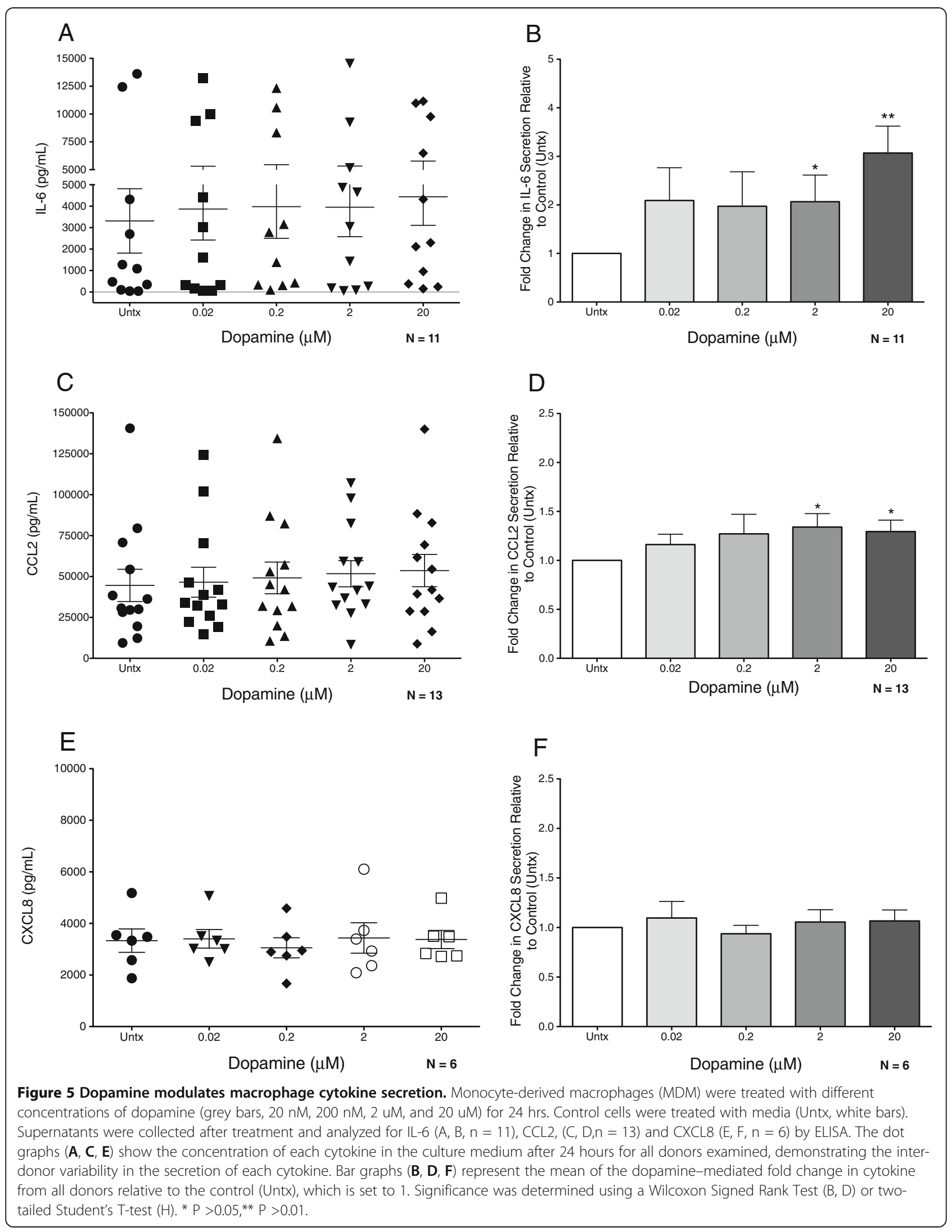


resulted in large inter-donor differences in cytokine secretion. In MDM not treated with LPS, dopamine had the most pronounced effect on IL-6, significantly increasing its elaboration by 2 and 3 fold at 2 and $20 \mu \mathrm{M}$ dopamine respectively $(\mathrm{n}=11$, Figure $5 \mathrm{~A}, 5 \mathrm{~B})$. Dopamine also significantly increased macrophage secretion of CCL2 by approximately 1.3 fold at $2 \mu \mathrm{M}$ and $20 \mu \mathrm{M}$ dopamine $(n=13$, Figure $5 C, 5 D)$, but did not have any significant effect on secretion of CXCL8 $(n=6$, Figure 5E, 5F). Changes in TNF- $\alpha$ or IL-10 secretion were not examined in non-LPS treated macrophages because secretion of these cytokines was undetectable in samples from many donors. In all MDM, LPS treatment induced a significant increase in the secretion of all cytokines except CCL2, as compared to MDM not treated with LPS. Dopamine significantly increased IL-6 secretion in LPS treated macrophages by 1.5 fold at $200 \mathrm{nM}$ $(\mathrm{n}=11$, Figure $6 \mathrm{~A}, 6 \mathrm{~B})$. Dopamine modulated CCL2 production in LPS treated macrophages similarly to non-LPS treated macrophages, significantly increasing CCL2 production approximately 1.4 fold at $200 \mathrm{nM}$ and $2 \mu \mathrm{M}$ dopamine, although not at $20 \mu \mathrm{M}$ dopamine $(\mathrm{n}=$ 10 , Figure $6 \mathrm{C}, 6 \mathrm{D})$. The only cytokine decreased by dopamine treatment was TNF- $\alpha$, as dopamine significantly reduced secretion of this cytokine approximately -1.3 to -1.4 fold in LPS treated macrophages at all concentrations examined $(n=12$, Figure $6 \mathrm{E}, 6 \mathrm{~F})$. Unlike in non-LPS treated cells, dopamine significantly increased CXCL8 in macrophages treated with LPS by approximately 1.3 fold at both $2 \mu \mathrm{M}$ and $20 \mu \mathrm{M}(\mathrm{n}=10$, Figure 6G, 6H). Dopamine also significantly increased IL-10 secretion in LPS treated cells approximately 1.7 fold at $2 \mu \mathrm{M}$ and $20 \mu \mathrm{M}(\mathrm{n}=10$, Figure 6I, 6J), and trended towards increases at lower dopamine concentrations, although these changes were not significant. These data demonstrate that dopamine regulates cytokine secretion in primary human macrophages.

\section{Discussion}

Dopamine is an immunoregulatory molecule, modulating the functions of rodent macrophages as well as human T-cells, in addition to its role as a neurotransmitter. Its effects on human macrophages and microglia had not been well characterized. We hypothesized that in the CNS of drug abusers or others with increased extracellular dopamine, dopamine-mediated changes in macrophage or microglial function would alter the development of neuroinflammation and the progression of several neurological diseases. We therefore determined whether human primary MDM express dopamine receptors and the dopaminergic machinery to respond to, synthesize, and take up dopamine. We showed that MDM express mRNA for all DR, as well as for DAT, VMAT2, TH and AADC. We demonstrated that MDM express D3R and D4R as well as DAT on the cell surface, VMAT2 on cellular membranes, and $\mathrm{TH}$ and AADC. We also showed that dopamine modulates the secretion of cytokines in both untreated and LPS-treated MDM. These findings indicate that macrophages express the proteins needed to respond to dopamine and that dopamine modulates macrophage functions.

Macrophages in the CNS in close proximity to neurons [52] are likely to be exposed to dopamine during spillover from the releasing synapse into the extrasynaptic space [53,54]. Extracellular dopamine concentrations in the human brain are not well characterized, but in rats the basal levels are estimated to be between 10 and $30 \mathrm{nM}[4,54]$ and can be increased to $250 \mathrm{nM}$ with a single electrical stimulus [3]. In both rodent and primate models, cocaine and methamphetamine increase extracellular dopamine in different regions of the brain $[1,2,55]$ and studies using cyclic voltammetry measured drug-induced dopamine flux to be as high as $500 \mathrm{nM}$ $5 \mu \mathrm{M}$ [56-58]. To model the effects of dopamine on macrophages in the brains of drug abusers and others with increased CNS dopamine, the concentrations of dopamine used in this study range from $20 \mathrm{nM}$ to $20 \mu \mathrm{M}$. We previously demonstrated that $20 \mu \mathrm{M}$ dopamine increases HIV replication in human macrophages [49]. Many other studies showed that dopamine concentrations within this range modulate different functions in rodent macrophages and microglia, as well as in human $T$ cells [17-24]. Dopamine mediates its effects primarily through activation of DR on the PM [30], although other dopamine mediated signaling pathways have been suggested by studies in rodent macrophages [22]. Dopamine receptor mRNA or protein was shown on rodent microglia [19] and human T-cells [20,40,59]. In T-cells, specific DR were shown to effect cytokine secretion [20], activation of regulatory T-cells [17] or $\beta 1$ integrin function [21]. In human macrophages DR subtypes had not been fully characterized. Our study shows that primary human macrophages have mRNA for all five subtypes of DR and express D3R and D4R in the PM. Our previous work showed MDM express D1R and D2R on the cell surface and showed specific activation of D2-like DR induces MAP kinase signaling [49]. Another study showed D1R in human macrophages [60], although its localization was not characterized. These studies demonstrate that DR are expressed on the surface of human macrophages and suggest that distinct DR subtypes may differentially modulate macrophage functions.

The effects of dopamine can also be regulated by DAT, VMAT2, TH and AADC. Our data show that primary human MDM express these proteins,. The dopamine transporter is localized to the PM and VMAT2 is in cellular membranes. Whether these proteins have a role in 

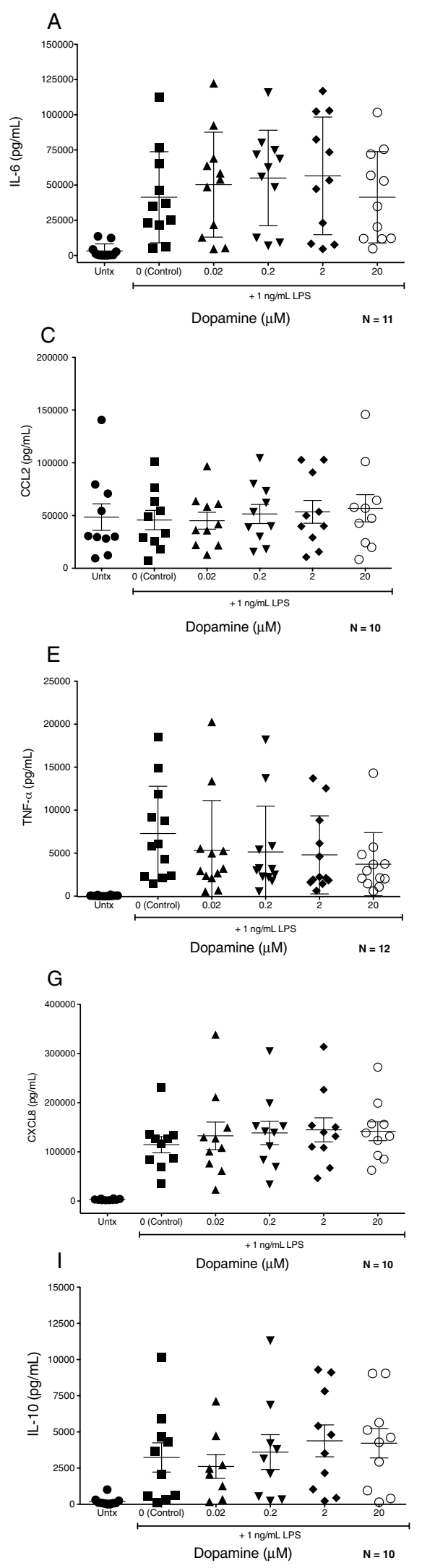

Figure 6 (See legend on next page.)
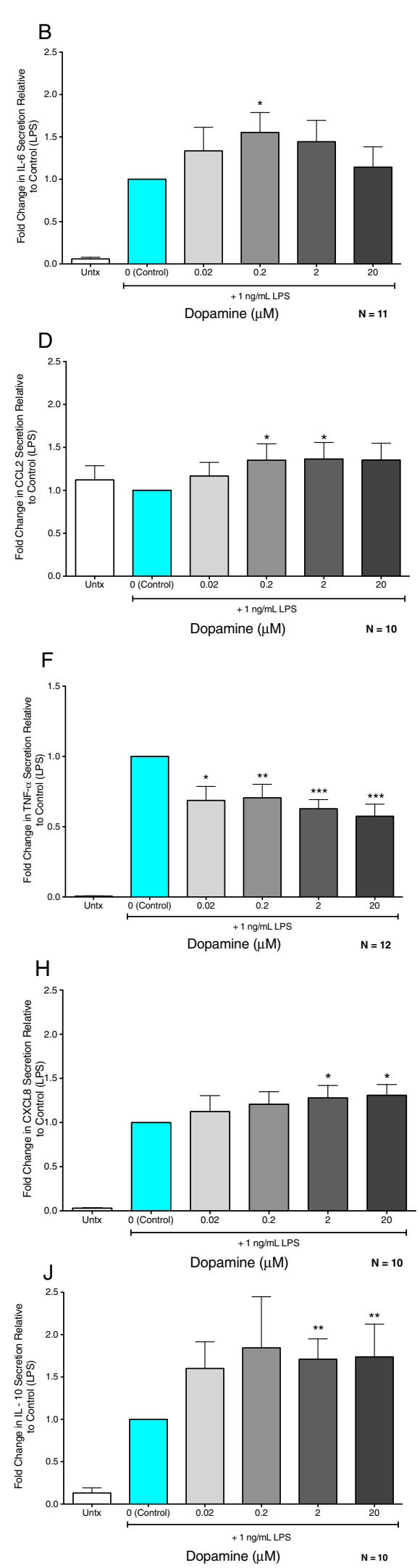
(See figure on previous page.)

Figure 6 Dopamine modulates LPS-induced macrophage cytokine secretion. MDM were treated with different concentrations of dopamine (grey bars, 20 nM, $200 \mathrm{nM}, 2 \mu \mathrm{M}$, and $20 \mu \mathrm{M}$ ) in conjunction with $1 \mathrm{ng} / \mathrm{mL}$ of LPS. Control cells (Control, blue bars) were treated with LPS only, while untreated MDM were treated with vehicle (Untx, white bars). Supernatants were collected after 24 hrs of treatment and analyzed for IL-6 (A, $B, n=11), \operatorname{CCL} 2(C, D, n=10)$, TNF-a $(E, F, n=12), C X C L 8(G, H, n=10)$ and IL-10 (I, J, $n=10)$ by ELISA. The dot graphs $(\mathbf{A}, \mathbf{C}, \mathbf{E}, \mathbf{G}, \mathbf{I})$ show the concentration of each cytokine in the culture medium after 24 hours for all donors examined, demonstrating the inter-donor variability in the secretion of each cytokine. Bar graphs $(\mathbf{B}, \mathbf{D}, \mathbf{F}, \mathbf{H}, \mathbf{I})$ represent the mean of the dopamine mediated fold change in cytokines from all donors relative to the control (LPS only), which was set to 1. Significance was determined using a Wilcoxon Signed Rank Test (B, D) or two-tailed Student's t-test $(H) .{ }^{*} P>0.05,{ }^{* *} P>0.01,{ }^{* * *} P>0.001$.

macrophage function is still unclear, as DAT was not found in a rodent macrophage cell line [61], while VMAT2 was expressed in promyelocytic human U937 cells but not in monocytic THP-1 cells [46,48]. However, functional DAT is expressed in human T-cells [62-64]. Tyrosine hydroxylase was detected in rodent macrophages [65], human T-cells [17] and human macrophages from arthritic tissue, although not in macrophages from non-arthritic controls [48], while AADC was found in human U937 cells and human Tcells $[38,47]$. Dopamine production has not been characterized in human macrophages, but low amounts of dopamine are synthesized in rodent macrophages $[65,66]$ and human PBMC $[17,40,67]$, and AADC in U937 cells is enzymatically active [47]. Dopamine uptake in human macrophages has also not been studied, but dopamine has been detected in cytoplasmic vesicles of human U937 cells and in rodent macrophages $[66,67]$. Together with our data, these studies suggest that human macrophages may take up, store, and synthesize dopamine, but the functional consequences of these actions remain unclear. In human CD4+/CD25+ regulatory T-cells, dopamine release and reuptake regulates an autocrine/paracrine loop through activation of D1-like DR to regulate IL-10 and TGF- $\beta$ production [17].

Our data show that dopamine also regulates IL-10 production in MDM, suggesting dopamine synthesis and/or dopamine uptake, storage and release may participate in regulation of macrophage cytokine production. Our data demonstrate that dopamine treatment alters macrophage production of IL-6, CCL2, TNF- $\alpha$, CXCL8 and IL-10. We found that 2 and $20 \mu \mathrm{M}$ dopamine significantly modulated secretion of all cytokines examined, while lower concentrations (20 and $200 \mathrm{nM}$ ) only altered TNF- $\alpha$, IL- 6 and CCL2 production by LPS-treated MDM. Lower concentrations of dopamine also showed a trend towards modulation of both IL- 6 in untreated MDM and IL-10 in LPS treated MDM, but these effects were not significant. Dopaminergic modulation of cytokines has been shown in both rodent macrophages [18,22] and human T-cells $[20,68]$ using similar concentrations of dopamine or using DR agonists. One study showed significant decreases in IL-2, IL-4 and IFN- $\gamma$ production from anti-CD3 activated human T-cells at lower dopamine levels (5-25 nM) [43]. The trend towards higher concentrations of dopamine being needed to induce significant cytokine secretion suggests that dopamine concentrations must be elevated above physiological levels to alter macrophage cytokine secretion.

Treatment of macrophages with LPS was used to model inflammatory conditions within the CNS. The effects of dopamine on LPS-treated macrophages indicate that macrophages in an inflammatory environment may respond differently to dopamine than do macrophages in homeostatic conditions. Elevated levels of LPS during HIV infection [69], and in individuals with HIVassociated dementia [70], suggest that macrophages in people with NeuroAIDS may respond differently to dopamine due to LPS-mediated activation. In our study, CXCL8 was signifcantly increased by dopamine treatment of LPS-treated MDM but was unaffected by dopamine in untreated cells. In contrast, treatment with 2 and $20 \mu \mathrm{M}$ dopamine increased IL- 6 2-to-3 fold in untreated cells, but increased IL- 6 only 1.5 fold, and only at $200 \mathrm{nM}$ dopamine, in LPS-treated macrophages. These data suggest that LPS activation of MDM primes the cells to respond differently to dopamine than nonLPS treated cells. Further investigation of changes in dopamine-mediated modulation of macrophage functions in response to inflammatory stimuli is an area of ongoing research. Dopamine mediated changes in cytokines have important implications for neuroinflammation. Elevated levels of CCL2 and CXCL8 may result in recruitment of peripheral blood monocytes, T-cells and neutrophils [71,72], increased blood brain barrier permeability [72,73] and altered migration of CNS cells [74]. Increases in IL-6, CCL2 and CXCL8 are associated with activation of perivascular macrophages and glia, and with the development of neurological diseases such as HAND, Alzheimer's disease, Parkinsons's or Huntington's disease, and multiple sclerosis [26,75-78].

Changes in cytokine production may also be beneficial, as decreases in TNF- $\alpha$ and increases in both IL-10 and CCL2 could limit neuroinflammation or be neuroprotective, depending on the kinetics and localization of their expression. For example, in Parkinson's disease, in which TNF- $\alpha$ plays a central role in the loss of dopaminergic neurons [79], decreases in this cytokine could reduce 
neuronal toxicity and slow disease progression [80]. Increases in CCL2 inhibit HIV-Tat induced apoptosis in neurons and astrocytes [81] and increased IL-10 facilitates neuronal recovery after traumatic brain injury by reducing inflammatory cytokine production [82]. Thus, changes in CNS dopamine which modulate macrophage secretion of the cytokines examined in this study may alter the CNS response to injury and infection, and significantly affect the pathogenesis of several neurological diseases $[25,75,83]$.

\section{Conclusion}

Macrophages are central to CNS homeostasis, immune and inflammatory response. Thus, the effects of elevated dopamine on macrophages may have a profound impact on neuroinflammation and the CNS response to insult as well as on the development of neurological diseases including Alzheimer's disease and HAND. The use of illegal drugs such as cocaine and methamphetamine increases CNS dopamine, and could therefore alter the development of neuroinflammation and modulate macrophage functions. Several therapeutic drugs also increase extracellular dopamine in the CNS, and may therefore have broader effects than treatment of a specific disease or condition. More detailed analyses of the actions of dopamine on macrophages are important for our understanding of the effects of legal and illegal dopaminergic drugs on the CNS. These studies will address the efficacy and safety of long-term treatment regimens as well as facilitate the development of novel interventional strategies for neurologic diseases in the context of drug abuse.

\begin{abstract}
Abbreviations
AADC: aromatic amino acid decarboxylase; BSA: bovine serum albumin; CNS: Central nervous system; DA: dopamine hydrochloride; DAPI: 4',6diamidino-2-phenylindole; DAT: dopamine transporter; DR: dopamine receptor; D1R: dopamine receptor 1; ELISA: enzyme-linked immunosorbent assay; FITC: fluorescein isothiocyanate; HAND: HIV-associated neurocognitive disorders; HEPES: hydroxyethyl piperazineethanesulfonic acid;

LPS: lipopolysaccharide; M-CSF: macrophage colony stimulating factor; MDM: Monocyte-derived macrophage; PBMC: peripheral blood mononuclear cells; PM: plasma membrane; PVDF: polyvinylidene fluoride; TBS: Tris-buffered saline; TH: Tyrosine hydroxylase; TNF: Tumor necrosis factor; VMAT2: vesicular monoamine transporter 2 .
\end{abstract}

\section{Competing interests}

The authors declare that they have no competing interests.

\section{Authors' contributions}

PJG designed the study with JWB, performed the immunoassays, subcellular fractionation and immunoblotting, and participated in the GRT-PCR with LC and the confocal microscopy with EAE, and drafted the manuscript. LC participated in the qRT-PCR with PJG and helped edit the manuscript. EAE performed the confocal microscopy with PJG and helped edit the manuscript. JWB participated in the design of the experiments with PJG, coordinated and helped to draft and edit the manuscript. All authors have read and approved the final version of this manuscript.

\section{Acknowledgements}

We thank all of the members of the Dr. Joan W. Berman Laboratory at Einstein for important discussions of the data and general support during this project. We also thank the Analytical Imaging Facility at Einstein for assistance with the confocal microscopy and the Einstein Center For AIDS Research (Al-051519) for use of their facilities and assistance designing the immunoassays. These studies were funded by the National Institutes of Drug Abuse grants DA029476 (PJG), DA026149 (LC and JWB), DA25567 (JWB) and the National Institutes of Mental Health grants MH096625 (EAE), MH090958 (LC and JWB), and MH075679 (JWB).

\section{Author details}

${ }^{1}$ Department of Pathology, Albert Einstein College of Medicine, Bronx, NY, USA. ${ }^{2}$ Public Department of Microbiology and Molecular Genetics, Health Research Institute, UMDNJ, Newark, NJ, USA. ${ }^{3}$ Department of Microbiology and Immunology, Albert Einstein College of Medicine, Bronx, NY, USA.

Received: 21 May 2012 Accepted: 3 July 2012

Published: 18 August 2012

\section{References}

1. Kimmel HL, Ginsburg BC, Howell LL: Changes in extracellular dopamine during cocaineself-administration in squirrel monkeys. Synapse 2005, 56(3):129-134

2. Desai RI, Paronis CA, Martin J, Desai R, Bergman J: Monoaminergic psychomotorstimulants: discriminative stimulus effects and dopamine efflux. J Pharmacol Exp Ther 2010, 333(3):834-843.

3. Garris PA, Ciolkowski EL, Pastore P, Wightman RM: Efflux of dopamine from the synaptic cleft in the nucleus accumbens of the rat brain. J Neurosci 1994, 14:6084-6093.

4. Gonon FG, Buda MJ: Regulation of dopamine release by impulse flow and byautoreceptors as studied by in vivo voltammetry in the rat striatum. Neuroscience 1985, 14:765-774.

5. Sulzer D, Zhang H, Benoit-Marand M, Gonon F: Regulation of Extracellular Dopamine: Release and Reuptake. In The Handbook of Basal Ganglia Structure and Function. First edn. Edited by Steiner HT, Kuei. Boston, MA: Academic Press; 2010:297-319.

6. D'Aquila PS, Collu M, Gessa GL, Serra G: The role of dopamine in the mechanism of action of antidepressant drugs. Eur J Pharmacol 2000, 405:365-373.

7. Lloyd KG, Davidson L, Hornykiewicz O: The neurochemistry of Parkinson's disease: effect of L-dopa therapy. J Pharmacol Exp Ther 1975, 195:453-464.

8. Ng KY, Chase TN, Colburn RW, Kopin IJ: L-Dopa-induced release of cerebral monoamines. Science 1970, 170(3953):76-77.

9. Volkow ND, Wang GJ, Fowler JS, Thanos PP, Logan J, Gatley SJ, Gifford A, Ding YS, Wong C, Pappas N: Brain DA D2 receptors predict reinforcing effects of stimulants in humans: replication study. Synapse 2002, 46:79-82.

10. Zhang L, Zhou FM, Dani JA: Cholinergic drugs for Alzheimer's disease enhance in vitro dopamine release. Mol Pharmacol 2004, 66:538-544.

11. Izzo E, Sanna PP, Koob GF: Impairment of dopaminergic system function after chronictreatment with corticotropin-releasing factor. Pharmacol Biochem Behav 2005, 81:701-708.

12. Maia TV, Frank MJ: From reinforcement learning models to psychiatric and neurological disorders. Nat Neurosci 2011, 14:154-162.

13. Krishnan V, Nestler EJ: The molecular neurobiology of depression. Nature 2008, 455(7215):894-902.

14. Scheller C, Arendt G, Nolting T, Antke C, Sopper S, Maschke M, Obermann M, Angerer A, Husstedt IW, Meisner F, et al: Increased dopaminergic neurotransmission in therapy-naiveasymptomatic HIV patients is not associated with adaptive changes at the dopaminergic synapses. J Neural Transm 2010, 117:699-705.

15. McGowan S, Lawrence AD, Sales T, Quested D, Grasby P: Presynaptic dopaminergicdysfunction in schizophrenia: a positron emission tomographic [18F]fluorodopa study. Arch Gen Psychiatry 2004, 61:134-142.

16. Mackay AV, Iversen LL, Rossor M, Spokes E, Bird E, Arregui A, Creese I: Synder SH:Increased brain dopamine and dopamine receptors in schizophrenia. Arch Gen Psychiatry 1982, 39:991-997. 
17. Cosentino M, Fietta AM, Ferrari M, Rasini E, Bombelli R, Carcano E, Saporiti F, Meloni F, Marino F, Lecchini S: Human CD4 + CD25+ regulatory T cells selectively express tyrosinehydroxylase and contain endogenous catecholamines subserving an autocrine/paracrine inhibitory functional loop. Blood 2007, 109:632-642.

18. Tarazona R, Gonzalez-Garcia A, Zamzami N, Marchetti P, Frechin N, Gonzalo JA, Ruiz-Gayo M, van Rooijen N, Martinez C, Kroemer G: Chlorpromazine amplifies macrophage-dependent IL-10 production in vivo. J Immuno 1995, 154:861-870.

19. Farber K, Pannasch U, Kettenmann H: Dopamine and noradrenaline control distinct functions in rodent microglial cells. Mol Cell Neurosci 2005, 29:128-138.

20. Besser MJ, Ganor Y, Levite M: Dopamine by itself activates either D2, D3 or D1/D5dopaminergic receptors in normal human T-cells and triggers the selective secretion of either IL-10, TNFalpha or both. J Neuroimmunol 2005, 169:161-171.

21. Levite M, Chowers Y, Ganor Y, Besser M, Hershkovits R, Cahalon L: Dopamine interactsdirectly with its D3 and D2 receptors on normal human T cells, and activates beta1integrin function. Eur J Immunol 2001 31:3504-3512

22. Hasko G, Szabo C, Nemeth ZH, Deitch EA: Dopamine suppresses IL-12 p40 production bylipopolysaccharide-stimulated macrophages via a betaadrenoceptor-mediatedmechanism. J Neuroimmunol 2002, 122:34-39.

23. Torres KC, Antonelli LR, Souza AL, Teixeira MM, Dutra WO, Gollob KJ: Norepinephrine, dopamine and dexamethasone modulate discrete leukocyte subpopulations andcytokine profiles from human PBMC. J Neuroimmunol 2005, 166:144-157.

24. Watanabe $Y$, Nakayama T, Nagakubo D, Hieshima K, Jin Z, Katou F, Hashimoto K, Yoshie O: Dopamine selectively induces migration and homing of naive CD8+ T cells via dopaminereceptor D3. J Immunol 2006, 176:848-856.

25. Rivest S: Regulation of innate immune responses in the brain. Nat Rev Immunol 2009, 9:429-439.

26. Minagar A, Shapshak P, Fujimura R, Ownby R, Heyes M, Eisdorfer C: The role of macrophage/microglia and astrocytes in the pathogenesis of three neurologicdisorders: HIV-associated dementia, Alzheimer disease, and multiple sclerosis. J Neurol Sci 2002, 202:13-23.

27. Block ML, Zecca L, Hong JS: Microglia-mediated neurotoxicity: uncovering the molecular mechanisms. Nat Rev Neurosci 2007, 8:57-69.

28. Molinoff PB, Axelrod J: Biochemistry of catecholamines. Annu Rev Biochem 1971, 40:465-500.

29. Daubner SC, Le T, Wang S: Tyrosine hydroxylase and regulation of dopamine synthesis. Arch Biochem Biophys 2011, 508:1-12

30. Missale C, Nash SR, Robinson SW, Jaber M, Caron MG: Dopamine receptors: from structure to function. Physiol Rev 1998, 78:189-25.

31. Horn AS: Dopamine uptake: a review of progress in the last decade. Prog Neurobiol 1990, 34:387-400

32. Mignini F, Tomassoni D, Traini E, Amenta F: Dopamine, vesicular transporters anddopamine receptor expression and localization in rat thymus and spleen. J Neuroimmunol 2009, 206:5-13.

33. Halbach Ov Bu, Dermietzel R: Neurotransmitters and neuromodulators: handbook of receptors and biological effects, 2nd. rev. and enl. ed edn. Weinheim: Wiley-VCH; 2006.

34. Kopin IJ: Monoamine oxidase and catecholamine metabolism. J Neural Transm Supp/ 1994, 41:57-67.

35. Weihe E, Eiden LE: Chemical neuroanatomy of the vesicular amine transporters. The FASEB journal: official publication of the Federation of American Societies for Experimental Biology 2000, 14(15):2435-2449.

36. McKenna F, McLaughlin PJ, Lewis BJ, Sibbring GC, Cummerson JA, BowenJones D, Moots RJ: Dopamine receptor expression on human T- and Blymphocytes, monocytes, neutrophils, eosinophils and NK cells: a flow cytometric study. J Neuroimmunol 2002, 132:34-40.

37. Alberio T, Anchieri C, Piacentini L, Gentile G, Simmaco M, Biasin M, Fasano M: Proteomic characterization of Jurkat T leukemic cells after dopamine stimulation: A model of circulating dopamine-sensitive cells. Biochimie 2011, 93:892-898.

38. Kokkinou I, Nikolouzou E, Hatzimanolis A, Fragoulis EG, Vassilacopoulou D: Expression of enzymatically active L-DOPA decarboxylase in human peripheral leukocytes. Blood Cells Mol Dis 2009, 42:92-98.

39. Amenta F, Bronzetti E, Cantalamessa F, El-Assouad D, Felici L, Ricci A Tayebati SK: Identification of dopamine plasma membrane and vesicular transporters in human peripheral blood lymphocytes. J Neuroimmunol 2001, 117:133-142.

40. Cosentino M, Marino F, Bombelli R, Ferrari M, Lecchini S, Frigo G: Endogenouscatecholamine synthesis, metabolism, storage and uptake in human neutrophils. Life Sci 1999, 64:975-981.

41. Kipnis J, Cardon M, Avidan H, Lewitus GM, Mordechay S, Rolls A Shani $Y$, Schwartz M: Dopamine, through the extracellular signalregulated kinase pathway, downregulates $C D 4+C D 25+$ regulatory T-cell activity: implications for neurodegeneration. The Journal of neuroscience: the official journal of the Society for Neuroscience 2004, 24:6133-6143.

42. Sarkar C, Das S, Chakroborty D, Chowdhury UR, Basu B, Dasgupta PS, Basu S: CuttingEdge: Stimulation of dopamine D4 receptors induce T cell quiescence by up-regulatingKruppel-like factor-2 expression through inhibition of ERK1/ERK2 phosphorylation. J Immunol 2006, 177:7525-7529.

43. Ghosh MC, Mondal AC, Basu S, Banerjee S, Majumder J, Bhattacharya D, Dasgupta PS: Dopamine inhibits cytokine release and expression of tyrosine kinases, Lck and Fyn in activated T cells. Int Immunopharmacol 2003, 3:1019-1026

44. Sookhai S, Wang JH, McCourt M, O'Connell D, Redmond HP: Dopamine induces neutrophilapoptosis through a dopamine D-1 receptorindependent mechanism. Surgery 1999, 126:314-322.

45. Sookhai S, Wang JH, Winter D, Power C, Kirwan W, Redmond HP: Dopamine attenuates thechemoattractant effect of interleukin-8: a novel role in the systemic inflammatoryresponse syndrome. Shock 2000, 14:295-299.

46. Anlauf M, Schafer MK, Schwark T, von Wurmb-Schwark N, Brand V, Sipos B, Horny HP, Parwaresch R, Hartschuh W, Eiden LE, et al: Vesicular monoamine transporter 2 (VMAT2) expression in hematopoietic cells and in patients with systemic mastocytosis. J Histochem Cytochem 2006, 54:201-213.

47. Kokkinou I, Fragoulis EG, Vassilacopoulou D: The U937 macrophage cell line expressesenzymatically active L-Dopa decarboxylase. J Neuroimmunol 2009, 216:51-58.

48. Capellino S, Cosentino M, Wolff C, Schmidt M, Grifka J, Straub RH: Catecholamine-producing cells in the synovial tissue during arthritis: modulation of sympatheticneurotransmitters as new therapeutic target. Ann Rheum Dis 2010, 69:1853.

49. Gaskill PJ, Calderon TM, Luers AJ, Eugenin EA, Javitch JA, Berman JW: Human immunodeficiency virus (HIV) infection of human macrophages is increased bydopamine: a bridge between HIVassociated neurologic disorders and drug abuse. Am J Pathol 2009, 175:1148-1159.

50. Rozen S, Skaletsky HJ: Primer3 on the WWW for general users and for biologist progammers. In Bioinformatics Methods and Protocols: Methods in Molecular Biology. Edited by Krawets S, Misener S. Totowa, NJ: Humana Press; 2000:365-386. Source code available at http://fokker.wi.mit.edu/ primer3

51. Altschul SF, Gish W, Miller W, Myers EW, Lipman DJ: Basic local alignment search tool. J Mol Biol 1990, 215:403-410.

52. Mallat $M$, Chamak B: Brain macrophages: neurotoxic or neurotrophic effector cells? J Leukoc Biol 1994, 56:416-422.

53. Cragg SJ, Rice ME: DAncing past the DAT at a DA synapse. Trends Neurosci 2004, 27:270-277.

54. Venton BJ, Zhang $H$, Garris PA, Phillips PE, Sulzer D, Wightman RM: Real-time decoding of dopamine concentration changes in the caudate-putamen during tonic and phasicfiring. J Neurochem 2003, 87:1284-1295

55. Schiffer WK, Azmoodeh M, Gerasimov M, Volkow ND, Fowler JS, Dewey SL: Selegilinepotentiates cocaine-induced increases in rodent nucleus accumbens dopamine. Synapse 2003, 48:35-38.

56. Phillips PE, Stuber GD, Heien ML, Wightman RM, Carelli RM: Subsecond dopamine release promotes cocaine seeking. Nature 2003, 422(6932):614-618.

57. Hermans A, Keithley RB, Kita JM, Sombers LA, Wightman RM: Dopamine detection withfast-scan cyclic voltammetry used with analog background subtraction. Anal Chem 2008, 80:4040-4048.

58. Zachek MK, Takmakov P, Park J, Wightman RM, McCarty GS: Simultaneous monitoring of dopamine concentration at spatially different brain locations in vivo. Biosens Bioelectron 2010, 25:1179-1185. 
59. Ilani T, Ben-Shachar D, Strous RD, Mazor M, Sheinkman A, Kotler M, Fuchs S: A peripheralmarker for schizophrenia: Increased levels of D3 dopamine receptor mRNA in bloodlymphocytes. Proc Natl Acad Sci U S A 2001, 98:625-628.

60. Liang $H$, Wang $X$, Chen $H$, Song L, Ye L, Wang SH, Wang YJ, Zhou L, Ho WZ: Methamphetamine enhances HIV infection of macrophages. Am J Pathol 2008, 172:1617-1624.

61. Rudd ML, Nicolas AN, Brown BL, Fischer-Stenger K, Stewart JK: Peritoneal macrophages express the serotonin transporter. J Neuroimmunol 2005, 159:113-118.

62. Marazziti D, Baroni S, Catena Dell'Osso M, Masala I, Fabbrini L, Betti L, Giannaccini G, Dell'osso B, Lucacchini A: Presence and characterization of the dopamine transporter inhuman resting lymphocytes. Neurochem Res 2008, 33:1011-1016

63. Caronti B, Antonini G, Calderaro C, Ruggieri S, Palladini G, Pontieri FE, Colosimo C: Dopamine transporter immunoreactivity in peripheral blood lymphocytes in Parkinson'sdisease. J Neural Transm 2001, 108:803-807.

64. Meredith EJ, Holder MJ, Rosen A, Lee AD, Dyer MJ, Barnes NM, Gordon J: Dopaminetargets cycling $B$ cells independent of receptors/transporter for oxidative attack: Implications for non-Hodgkin's lymphoma. Proc Natl Acad Sci U S A 2006, 103:13485-13490.

65. Brown SW, Meyers RT, Brennan KM, Rumble JM, Narasimhachari N, Perozzi EF, Ryan JJ, Stewart JK, Fischer-Stenger K: Catecholamines in a macrophage cell line. J Neuroimmunol 2003, 135:47-55.

66. Flierl MA, Rittirsch D, Nadeau BA, Chen AJ, Sarma JV, Zetoune FS, McGuire SR, List RP, Day DE, Hoesel LM, et al: Phagocyte-derived catecholamines enhance acute inflammatory injury. Nature 2007, 449(7163):721-725.

67. Cosentino M, Bombelli R, Ferrari M, Marino F, Rasini E, Maestroni GJ, Conti A, Boveri M, Lecchini S, Frigo G: HPLC-ED measurement of endogenous catecholamines in humanimmune cells and hematopoietic cell lines. Life Sci 2000, 68:283-295.

68. Ilani $T$, Strous RD, Fuchs S: Dopaminergic regulation of immune cells via D3 dopaminereceptor: a pathway mediated by activated T cells. The FASEB journal: official publicationof the Federation of American Societies for Experimental Biology 2004, 18:1600.

69. Brenchley JM, Price DA, Schacker TW, Asher TE, Silvestri G, Rao S, Kazzaz Z, Bornstein E, Lambotte $O$, Altmann D, et al: Microbial translocation is a cause of systemic immuneactivation in chronic HIV infection. Nat Med 2006, 12:1365-1371.

70. Ancuta P, Kamat A, Kunstman KJ, Kim EY, Autissier P, Wurcel A, Zaman T, Stone D, Mefford M, Morgello S, et al: Microbial translocation is associated with increased monocyteactivation and dementia in AIDS patients. PLOS One 2008, 3:e2516.

71. Gouwy M, Struyf S, Noppen S, Schutyser E, Springael JY, Parmentier M, Proost P, VanDamme J: Synergy between coproduced CC and CXC chemokines in monocytechemotaxis through receptor-mediated events. Mol Pharmacol 2008, 74:485-495.

72. Eugenin EA, Osiecki K, Lopez L, Goldstein H, Calderon TM, Berman JW: CCL2/monocytechemoattractant protein-1 mediates enhanced transmigration of humanimmunodeficiency virus (HIV)-infected leukocytes across the blood-brain barrier: apotential mechanism of HIVCNS invasion and NeuroAIDS. The Journal of neuroscience: the official journal of the Society for Neuroscience 2006, 26:1098-1106.

73. Kossmann T, Stahel PF, Lenzlinger PM, Redl H, Dubs RW, Trentz O, Schlag G, Morganti-Kossmann MC: Interleukin-8 released into the cerebrospinal fluid after brain injury isassociated with blood-brain barrier dysfunction and nerve growth factor production. Journal of cerebral blood flow and metabolism: official journal of the International Society ofCerebral Blood Flow and Metabolism 1997, 17(3):280-289.

74. McManus CM, Liu JS, Hahn MT, Hua LL, Brosnan CF, Berman JW, Lee SC: Differential induction of chemokines in human microglia by type I and II interferons. Glia 2000, 29:273-280.

75. Cacquevel M, Lebeurrier N, Cheenne S, Vivien D: Cytokines in neuroinflammation and Alzheimer's disease. Curr Drug Targets 2004, 5:529-534.

76. Xiong H, Boyle J, Winkelbauer M, Gorantla S, Zheng J, Ghorpade A, Persidsky Y, Carlson KA, Gendelman HE: Inhibition of long-term potentiation by interleukin-8: implications forhuman immunodeficiency virus-1-associated dementia. J Neurosci Res 2003, 71:600-607.
77. Frank-Cannon TC, Alto LT, McAlpine FE, Tansey MG: Does neuroinflammation fan the flame in neurodegenerative diseases? Mol Neurodegener 2009, 4:47

78. Blum-Degen D, Muller T, Kuhn W, Gerlach M, Przuntek H, Riederer P: Interleukin- 1 beta and interleukin- 6 are elevated in the cerebrospinal fluid of Alzheimer's and de novoParkinson's disease patients. Neurosci Lett 1995, 202:17-20.

79. McGuire SO, Ling ZD, Lipton JW, Sortwell CE, Collier TJ, Carvey PM: Tumor necrosis factor alpha is toxic to embryonic mesencephalic dopamine neurons. Exp Neurol 2001, 169:219-230.

80. McCoy MK, Martinez TN, Ruhn KA, Szymkowski DE, Smith CG, Botterman BR, Tansey KE, Tansey MG: Blocking soluble tumor necrosis factor signaling with dominant-negativetumor necrosis factor inhibitor attenuates loss of dopaminergic neurons in models of Parkinson's disease. The Journal of neuroscience: the official journal of the Society for Neuroscience 2006, 26:9365-9375

81. Eugenin EA, Berman JW: Chemokine-dependent mechanisms of leukocyte traffickingacross a model of the blood-brain barrier. Methods 2003, 29:351-361.

82. Knoblach SM, Faden Al: Interleukin-10 improves outcome and alters proinflammatorycytokine expression after experimental traumatic brain injury. Exp Neurol 1998, 153:143-151.

83. Ziebell JM, Morganti-Kossmann MC: Involvement of pro- and antiinflammatory cytokinesand chemokines in the pathophysiology of traumatic brain injury. Neurotherapeutics: the journal of the American Society for Experimental NeuroTherapeutics 2010, 7:22-30.

doi:10.1186/1742-2094-9-203

Cite this article as: Gaskill et al:: Characterization and function of the human macrophage dopaminergic system: implications for CNS disease and drug abuse. Journal of Neuroinflammation 2012 9:203.

\section{Submit your next manuscript to BioMed Central and take full advantage of:}

- Convenient online submission

- Thorough peer review

- No space constraints or color figure charges

- Immediate publication on acceptance

- Inclusion in PubMed, CAS, Scopus and Google Scholar

- Research which is freely available for redistribution 